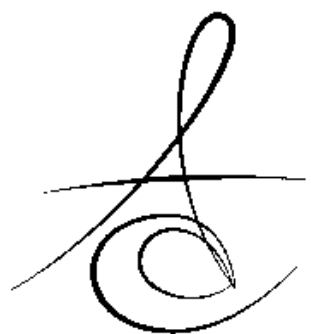

\title{
AKTİNOMİKOZ OSTEOMYELİTİNE BAĞLI PATOLOJİK MANDİBULA FRAKTÜRÜ: OLGU SUNUMU
}

\section{A PATHOLOGICAL FRACTURE OF THE MANDIBLE DUE TO ACTINOMICOSIS OSTEOMYELITTIS: A CASE REPORT}

\author{
Dt. Burak CEZAİRLí ${ }^{*}$ \\ Yrd. Doç. Dr. Celal ÇANDIRLI*
}

\author{
Prof. Dr. Kadriye YILDIZ*
}

Dr. Dt. Cem ÜNGÖR*

Makale Kodu/Article code: 1210

Makale Gönderilme tarihi: $16.06 . .2013$

Kabul Tarihi: $\quad 09.09 .2013$

\section{ÖZET}

Aktinomikozis mantar enfeksiyonu gibi görülse de anaerob gram(+) bakterilerinin meydana getirdiği spesifik ve kronik bir enfeksiyondur. Toraks, abdominal bölge ve genital bölgelerde görülebilmekle beraber en sık servikofasial bölgede izlenir. Bu olgu sunumunda aktinomikoz enfeksiyonu nedeniyle oluşan bir patolojik fraktürün tedavisini anlatmayı amaçladık. 64 yaşındaki erkek hasta, alt çene sol angular bölgesindeki ağrı şikayeti ile kliniğimize başvurmuştur. Yapılan klinik, radyolojik ve mikrobiyolojik değerlendirmeler sonrasında hasta, aktinomikoz enfeksiyonuna bağlı patolojik fraktür tanısıyla tedavi edilmiştir. Hastanın tedavi sonrasında yapılan klinik ve radyolojik takibinde, sorunsuz olarak iyileştiği ve herhangi bir patoloji gelişmediği tespit edilmiştir.

Anahtar kelimler: Aktinomikozis, patolojik fraktür, fraktür fiksasyonu

\section{ABSTRACT}

Actinomycosis is a specific and chronic infection caused by gram-positive anaerobic bacteria which is mostly miss diagnosed as fungal infections. While the cervicofacial form has the highest prevelance, it can also be seen in thorax, abdominal and genital region. In this case we reported a pathologic fracture treatment caused by actinomycosis infection. 64 years-old male patients refered to our clinic with pain on left mandibular angulus. Patient is treated with a diagnose of a fracture due to actinomycosis infection after the clinical, radiologic and microbyologic examinations. After the treatment, patient recovered uneventfully and the development of/any pathology was not detected according to clinic and radiographic examination.

Key words: Actinomycosis, pathological fracture, fracture fixation

\section{GİRIŞ}

Aktinomikozis mantar enfeksiyonu gibi görülse de insanlara karşı patojenik olan anaerob gram(+) aktinomikoz bakterilerinin meydana getirdiği spesifik ve kronik bir enfeksiyondur. Toraks, abdominal bölge ve genital bölgelerde görülebilmekle beraber en sık servikofasial bölgede izlenir. ${ }^{1}$ Kronik ve inatçı bir enfeksiyondur. Ayrıca spontan gelişen ve lezyona özgü sülfür granülleri içeren drenaj yolları sebebiyle fibrotik, endure ve nodüler bir yapı gösterebilirler. ${ }^{1}$

Oral florada en sık izlenen aktinomikoz (A) türleri $A$. viscous, $A$. naeslundii, $A$. odontolyticus ve $A$. meyerii ${ }^{2}$ olup en sık enfeksiyona neden olan tür ise $A$ israeli'dir. Normalde ağız florasında yer alan bu bakteriler tonsil kriptalarında, gingival çatlaklarda, çürük dentinde, mukoza yüzeylerinde ve çekim bölgelerine yerleşebilirler. $^{3}$

Aktinomikoz enfeksiyonu olabilmesi için öncelikle mukozanın bir travma sebebiyle-devamlılğının bozulması gereklidir. Bütünlüğün bozulmasını takiben doku içerisine penetre olan bakteriler başka bakterilerin sinerjik etkisiyle oluşan anaerobik ortamda hızla çoğalırlar. Enfeksiyonun başlaması zor olmakla birlikte meydana geldikten sonra enfeksiyonu tamamıyla elimine etmek çok zordur. ${ }^{3}$ Genelde enfekte dokular ciddi nekrozis ve fibrosis alanları içerirler. Sadece yumuşak doku tutulumu oluşturabilirler veya yumuşak dokunun yanında kemiği tutarak aktinomikoz osteomyeliti de meydana getirebilirler. Kemik

\footnotetext{
* Karadeniz Teknik Üniversitesi, Diş Hekimliği Fakültesi, Ağız Diş Çene Hastalıkları ve Cerrahisi Anabilim Dalı

${ }^{* *}$ Karadeniz Teknik Üniversitesi, Tıp Fakültesi, Patoloji Anabilim Dalı
} 
enfeksiyonları daha ciddi ilerleyebilmekle beraber maksillada nadir görülüp kafa içine yayılma riski vardır. Tedavisinde oluşturduğu bu bariyeri aşabilecek yüksek doz antibiyotikler kullanııı. ${ }^{4}$

$$
\text { Aktinomikozların meydana getirdiği }
$$

osteomyelitlerle ilgili literatürde kısıtlı sayıda yayın mevcuttur. Enfeksiyon yumuşak dokuyu geçip periosta ulaştığı zaman periostitis meydana gelir ve eğer enfeksiyon yavaş ilerliyorsa bu kendini reaksiyonel olarak periostun meydana getirdiği yeni kemik oluşumu olarak gösterir. Hızlı ilerleyen enfeksiyonlarda ise kemik içine doğru uzanan destrüksiyon alanları izlenebilir. ${ }^{5}$ Kronik osteomyelit nedeniyle oluşan bu destrükte kemik bölgelerinde patolojik fraktürler izlenebilir. $^{6}$

$\mathrm{Bu}$ olgu sunumunda, aktinomikoz enfeksiyonu nedeniyle oluşan osteomyelit ve durumun inmali sonucu gelişen patolojik fraktürün klinik ve radyolojik bulguları ve tedavisi sunulmuştur.

\section{OLGU SUNUMU}

74 yaşındaki erkek hasta sol alt çene angulus bölgesindeki ağrı şikayetiyle Karadeniz Teknik Üniversitesi Diş Hekimliği Fakültesi Ağız Diş Çene Cerrahisi Anabilim Dalı'ına başvurmuştur.

Hastanın alınan anamnezinde, mandibula sol angulus bölgesinden 36 ve 37 nolu dişlerinin çekildiği, bölgenin iyileşmediği ve zamanla artan bir ağrı ile birlikte sol alt dudak bölgesinde parestezi geliştiği tespit edilmiştir. Ayrıca hastanın daha önce boyun bölgesindeki bir kitle sebebiyle mukoepidermoid karsinom tanısıyla total parotidektomi ile kombine radikal boyun diseksiyonu operasyonu geçirdiği ve cerrahi sonrası ilgili bölgeden 2 ay süresi boyunca haftada bir kez radyoterapi tedavisi aldığı belirlenmiştir. Hasta ayrıca prostat büyümesi sebebiyle medikal tedavi gördüğünü belirtmiştir.

Yapılan klinik muayenede çekim bölgesinde ekspoze kemik, submandibular lenfoadenopati, pürülan akıntı ve mandibula sol angulus bölgesinde palpasyonda ağrılı ekspansiyon görülmüştür (Resim-1). Radyografik muayenede ise çekim bölgesi ve çevresinde güve yeniği şeklinde radyolüsent lezyonlar izlenmiştir. Çekim bölgesindeki sekestre kemiğin histopatolojik incelemesi sonucunda lezyonun aktinomikoz kaynaklı osteomyelit olduğu teşhis edilmiştir. Histopatolojik incelemede nekrotik kemik

trabekülaları arasında akut iltihabi eksuda ve aktinomiçes kolonileri "sülfür granülleri" ve bakterilerin yer yer periferde Işınsal dizilim gösterdiği Grocott (+)aktinomiçes kolonileri izlenmektedir (Resim-2,3,4).

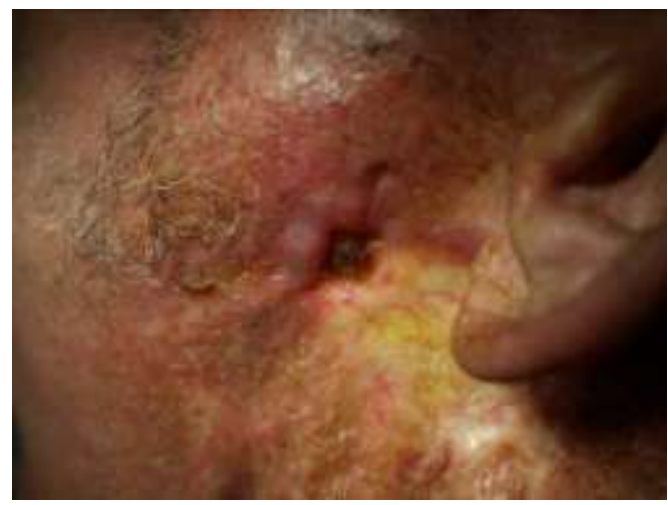

Resim 1. Lezyonun preoperatif ekstraoral görüntüsü

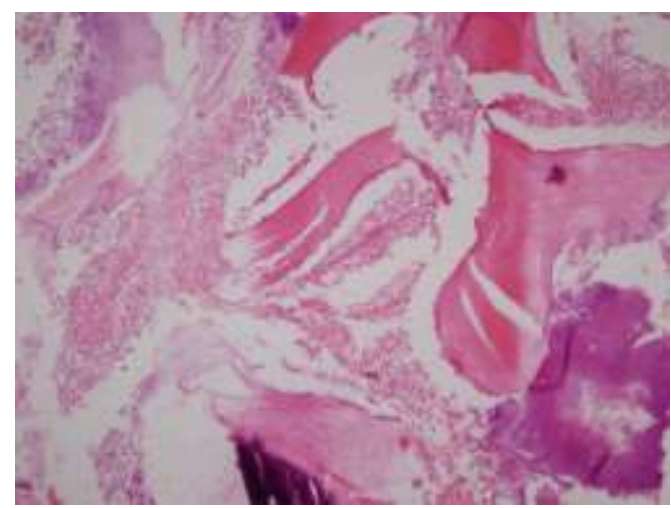

Resim-2: Nekrotik kemik trabekülaları arasında akut iltihabi eksuda ve sağ alt ve sol lüst köşede aktinomiçes kolonileri "sülfür granülleri" (HEx200)

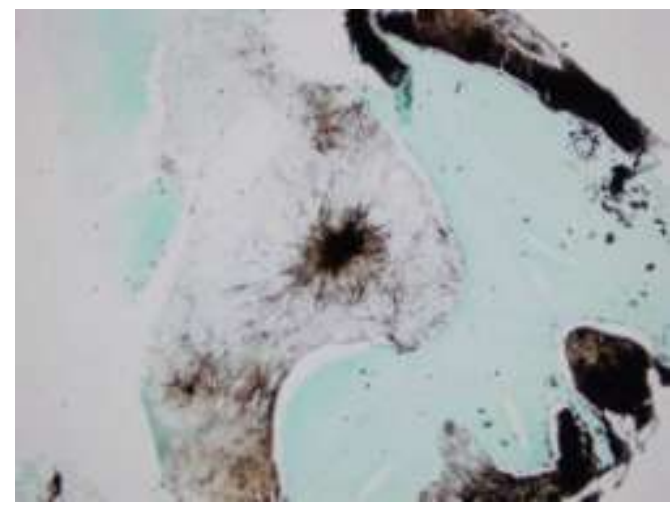

Resim 3. Nekrotik kemik trabekülaları (açık yeşil renkte) ve arada bakterilerin yer yer periferde ışınsal dizilim gösterdiği Grocott (+)aktinomiçes kolonileri (siyah renkte) (Grocott x 200) 
Hastaya antibiyotik tedavisi ile birlikte sekestrotomi planlanmış olmasına rağmen ameliyat günü hasta randevusuna gelmemiştir. Üç ay sonra hasta kliniğimize aynı bölgede gelişen ekstraoal fistül ile birlikte patolojik mandibula angulus fraktürü ile müracaat etmiştir.

Sedasyon altında hasta opere edilip fraktürün redüksiyonu için fistül yolunu kapsayan ekstraoral cerrahi yaklaşım tercih edilip nekroze kemik uzaklaştırıldıktan sonra iki tane 6 delikli rekonstrüksiyon plağı (Biomet, Warsaw, Indiana, A.B.D) ile fraktür redükte edilmiştir (Resim-5). İnsizyon hattı üzerindeki fistül yolları eksize edildikten sonra kas dokusu 4.0 Vicryl ve cilt 5.0 Propilen sütur ile primer olarak kapatılmıştır.

Cilt üzerindeki insizyon bölgesinin işlemden 1 hafta sonra yaklaşık 2 hafta süreyle her gün Betakon (Povidon, Aroma İlaç Sanayi) ile irrige edilip Fucidin pomad (Fusidik Asit, Abdi İbrahim İlaç) ile pansuman yapılmıştır ve bu sürenin sonunda iyileşme tamamlandığı belirlenmiştir. Hastanın 10 ay sonunda yapılan intraoral, ekstraoral ve radyolojik muayenesinde patolojik duruma rastlanılmamıştır (Resim-6,7,8).

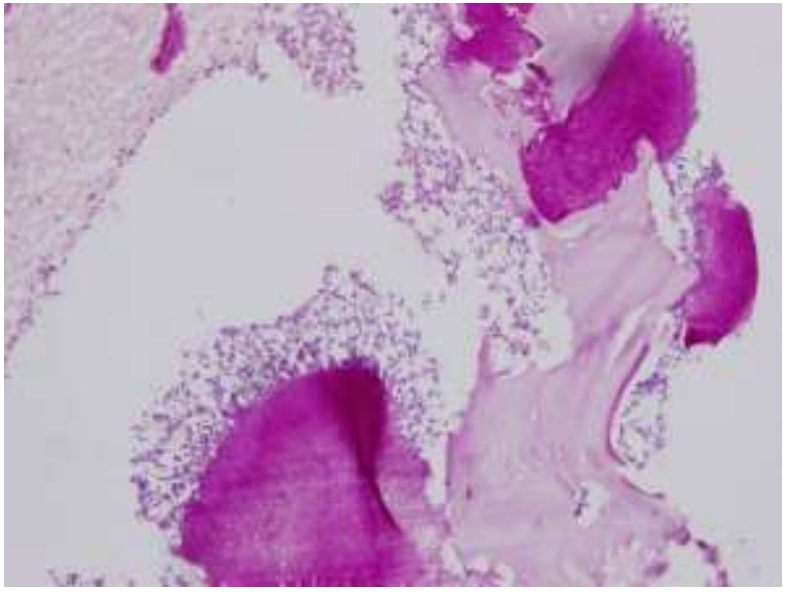

Resim 4. Nekrotik kemik trabekülaları ve akut iltihabi eksuda kitleleri arasında PAS(+)sülfür granülleri (PASXx200)

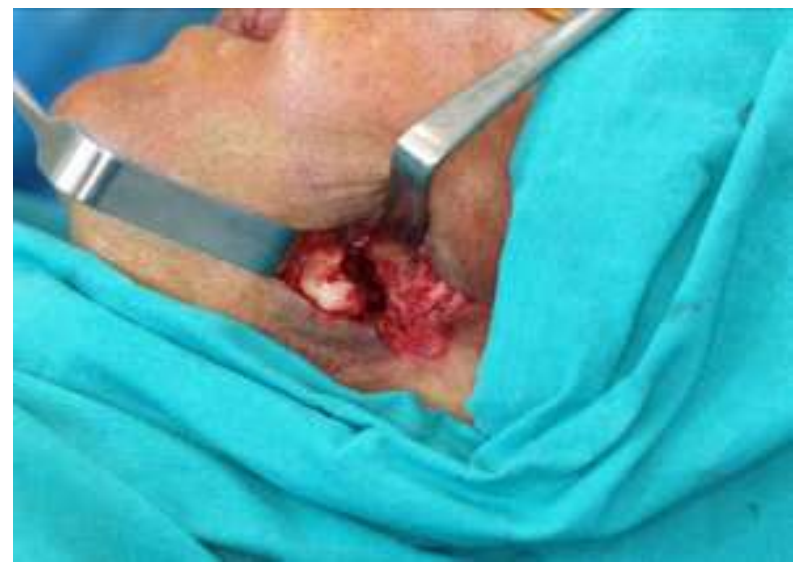

Resim 5. Fraktür hattının intraoperatif görüntüsü

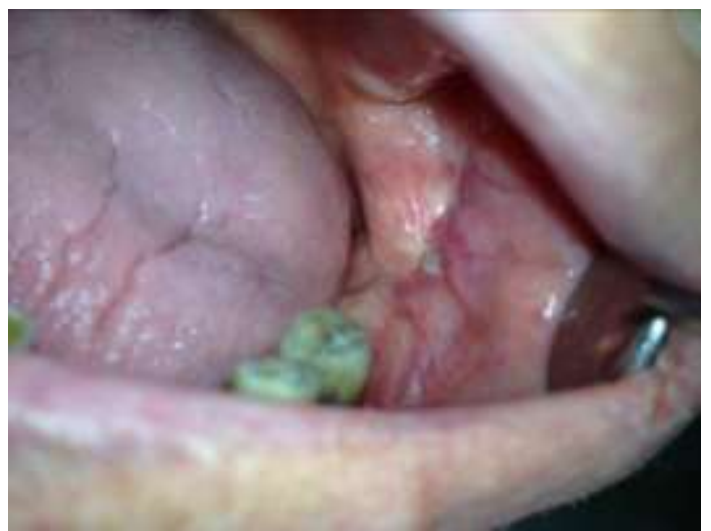

Resim 6. Hastanın postoperatif 10.ay intraoral görüntüsü

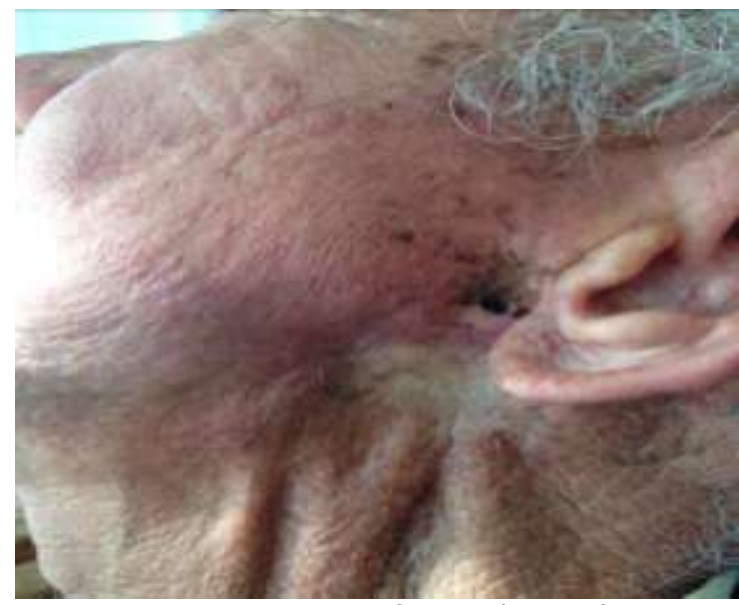

Resim 7. Hastanın postoperatif 10.ay ekstraoral görüntüsü

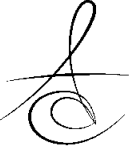




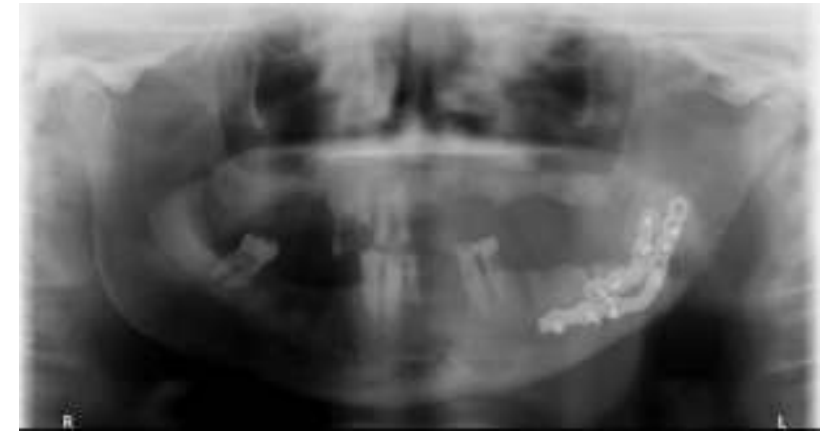

Resim 6. Hastanın postoperatif 10.ay panaromik radyografisi

\section{TARTIŞMA}

Aktinomikozis nadir görülen ve sıklıkla kommensal saprofit bakterilerin neden olduğu zayıflamış konak savunmasını geçerek derin dokulara yayılma potansiyeline sahip bir enfeksiyondur. Bu bakteriler düşük seviyeli virülans etkiye sahip oldukları için patojenik özellikleri konak savunmasının hassasiyetine bağlıdır. ${ }^{4}$ Sıklıkla dental, oral cerrahi ve travma kaynaklı olarak servikofasiyal bölge de izlenmekle birlikte vücudun herhangi bir yerinde enfeksiyona neden olabilirler. $^{5}$

Aktinomikozisin ayrıcı tanısı tüberküloz, malign tümöral oluşumlar ve mantar enfeksiyonu gibi farklı lezyonların yanı sıra üst çeneyi nadir tutmakla birlikte minör tükrük bezlerinin neoplazmları ve lenfoma ile yapılır. $^{7}$ Klinik ve radyolojik bulgulara ek olarak mikrobiyolojik ve histolojik incelemeler de tanı koyulmasına yardımc olur. Servikofasiyal aktinomikozda sıklıkla servikal lenfoadenopati izlenir ve malign neoplazmlarla ile ayırıc tanısında bu klinik bulgudan sıklıkla faydalanılır.

Literatürde, radyoterapinin aktinomikoz enfeksiyonun gelişiminde predispozan faktör olduğu düşünülmektedir. ${ }^{8}$ Radyoterapi sonrası ilgili bölgenin vaskülarizasyonun azaldığı tespit edilmiş olup hiperbarik oksijen tedavisinin enfeksiyon bölgesinde vaskülarizasyonun artmasını sağlayacağı rapor edilmiştir. ${ }^{5,9}$

Aktinomikoz enfeksiyonlarının tedavi seçeneği olarak cerrahi debridman sıklıkla tercih edilmektedir. Ayrıca seçilen tedavi metodunun asıl amacı olarak anaerobik ortamı değiştirmek, organizma sayısını azaltmak ve fistül yollarını eksize etmek belirlenmiştir. Yumuşak dokuda nekroze dokuların ve nadiren etkilenmiş lenf nodlarının eksizyonu yeterli olurken, kemik tutulumu olan vakalarda lezyon boyutlarına bağlı olarak basit küretaj ve dekortikasyon uygulanabilir. $^{5}$ A. israelii iyoda karşı duyarlı olduğu için iyot içeren solüsyonların kürete edilen bölgeye uygulanması ve boşluklara iyodoformlu fitil ve patların yerleştirilmesi günümüzde de kullanılan bir tedavi şeklidir. ${ }^{10}$

Aktinomikoz tedavisinde cerrahi debridmana ek olarak geniş spektrumlu antibiyotik uygulanabilir. ${ }^{11}$ Antibiyotiklerin lezyonun içerisindeki mikro bakteri kolonilerine penetre olabilmesi için intravenöz (IV) olarak yüksek dozda kullanılmaları uygundur., ${ }^{3,5}$ Antibiyotik olarak genelde klindamisin ve penisilin grupları tercih edilmektedir. Ayrıca bazı vakalarda tetrasiklin türevi antibiyotikler kullanıldığı rapor edilmiştir. Yapılacak olan medikal tedavi uzunluğu klinik ve patolojik yanıta bağlıdır ve buna göre belirlenir. $^{12}$ Sunduğumuz olguda, tedavi yöntemi olarak preoperatif IV penisilin $1000 \mathrm{mg}$ günde $2 \mathrm{kez}$ olmak üzere 14 gün uygulanmıştır. Ayrıca lezyonun cerrahi eksizyonunu takiben patolojik fraktür 2 adet rekonstrüksüyon plağı ile redükte edilmiştir.

Aktinomikoz enfeksiyonları, baş ve boyun bölgesinde en sık perimandibular bölgede izlenir. Bu bölgede görülen enfeksiyonlarda da kemik tutulumu oldukça nadirdir. ${ }^{13}$ Uygun tedavi protokolleri eşliğinde aktinomikozisin tedavisi vakalarından \%90'ından başarıyla sağlanabilir. ${ }^{8}$ Vakamızda tedaviden 10 ay sonra hastanın klinik olarak şikayetlerinin bulunmadığı görülmüştür ve kontrol radyografilerinde fraktür hattında gelişen sekonder kemik oluşumu izlenmiştir.

Aktinomikoz tanısı, detaylı olarak yapılan klinik ve radyolojik muayene bulgularına ek olarak yapılan mikrobiyolojik tetkikler yardımı ile koyulur. Anaerobik kültürler bakterinin izole edilmesini sağlamakla beraber günümüzde polimeraz zincir tepkimesi (PZT) bakterinin tespitinde önemli rol oynamaktadır. ${ }^{14,15}$ Aktinomikoza bağlı enfeksiyonlar ve bu enfeksiyona bağlı patolojik fraktürler ise servikofasiyal bölgede nadir olarak görülürler. Sunduğumuz vakada; aktinomikoza bağlı olarak oluşan patolojik fraktür tanısı ve tedavisi değerlendirilmiştir. Yapılan tedavi sonucunda, 20 aylık takipler sonrasında sorunsuz iyileşme sağlanmıştır.

Aktinomikoz oral mukozadan infiltre olması durumunda mandibulada inatçı ve şiddetli enfeksiyon oluşturabilecek bir patojendir. Anaerobik koşullarda oluşturulan kültürler enfeksiyonun teşhisine yardımcı 
olmaktadır. Ayrıca uygun antimikrobiyal tedavi seçilmesi hastalığın prognozu açısından önemlidir. Klinisyenler bu konuda dikkatli olmalı ve uygun tedavi seçeneklerini tercih etmelidir.

\section{KAYNAKLAR}

1. Robert E. Marx, Diane Stern, Oral and Maillofacial Pathology: A Rationale for Diagnosis and Treatment. 2003 Quintessence Publishing Co, Inc.

2. Herman WW, Whitaker SB, Williams MF, Sangueza OP. Acute actinomycosis presenting as an ulcerated palatal mass . J Oral Maxillofac Surg 1998;56:1098-101.

3. Rubin MM, Krost B. Actinomycosis Presenting as a midline palatal defect. J Oral Maxillofac Surg 1995;53:701-3.

4. Russo TA: Agents of actinomycosis, in Mandell GL, Bennett JE, Dolin R (eds): Principles and Practice of infectious Disease (ed 4). New York, NY, Churchill Livingstone, 1995. p. 2280-2288.

5. Chung Ji Liu, Kuo Ming Chang, Chia Teh Ou. Actinomycosis in a patient treated for maxillary osteoradionecrosis. J Oral Maxillofac Surg 1998;56:251-3.

6. Kaya GŞ, Yalçın E, Aras MH, Gürsan N. Kronik osteomyelitin postoperatif komplikasyonu ve tedavisi. J Dent Fac Atatürk 2011;21:39-42.

7. Bennoff DF: Actinomycosis: Diagnostic and therapeutic considerations and a rewiev of 32 cases. Laryngoscope 1984;94:1198-201.

8. Weese WC, Smith IM. A study of 57 cases actinomycosis over 36-year period: A diagnostic "failure" with good prognosis after treatment. Arch Intern Med 1975;135:1562-5.

9. Beehner MR, Marx RE: Hyperbaric oxygen induced angiogenesis and fibroplasia in human irridated tissue (abstr). Proceedings of the 65th meeting of the American Association of Oral and Maxillofacial Surgeons, Las Vegas, NV, Semptember 21,1983.

10. Ünür $M$, Onur ÖD. Aktinomikoz: Ağız Hastalıklarının Teşhis ve Tedavisi. 1. baskı. İstanbul, Quintessence Yayıncılık, 2003. s. 175-7.

11. Ömer Günhan: Oral ve Maksillofasiyal Patoloji. 1.baskı. Ankara, Atlas Kitapçlık Itd. şti. 2001. p. 185-6
12. Brook I. Actinomycosis: diagnosis and management. South Med J 2008;101: 1019-23.

13. Smith MH, Harms PW, Newton DW, Lebar B, Edwards SP, Aronoff DM. Mandibular Actinomyces osteomyelitis complicating florid cemento-osseous dysplasia: case report. BMC Oral Health 2011;21: 21.

14. Hansen T, Wagner W, Kirkpatrick CJ, Kunkel M. Infected osteoradionecrosis of the mandible: follow-up study suggests deterioration in outcome for patients with Actinomyces-positive bone biopsies. Int J Oral Maxillofac Surg 2006;35: 1001-4.

15. Sharkawy AA. Cervicofacial actinomycosis and mandibular osteomyelitis. Infect Dis Clin North Am 2007;25: 543-6.

\section{Yazışma Adresi}

Cem Üngör

Karadeniz Technical University Faculty of Dentistry Department of Oral and Maxillofacial Surgery, Trabzon, TURKEY

Tel00 905322403191

Fax00 904623773017

e-mailcem_ungor@yahoo.com 